\title{
Do older workers have more trouble using a computer than younger workers?
}

Citation for published version (APA):

Borghans, L., \& ter Weel, B. J. (2002). Do older workers have more trouble using a computer than younger workers? Researchcentrum voor Onderwijs en Arbeidsmarkt, Faculteit der Economische Wetenschappen. ROA Research Memoranda No. 1E https://doi.org/10.26481/umaror.200201E

Document status and date:

Published: 01/01/2002

DOI:

10.26481/umaror.200201E

Document Version:

Publisher's PDF, also known as Version of record

\section{Please check the document version of this publication:}

- A submitted manuscript is the version of the article upon submission and before peer-review. There can be important differences between the submitted version and the official published version of record.

People interested in the research are advised to contact the author for the final version of the publication, or visit the DOI to the publisher's website.

- The final author version and the galley proof are versions of the publication after peer review.

- The final published version features the final layout of the paper including the volume, issue and page numbers.

Link to publication

\footnotetext{
General rights rights.

- You may freely distribute the URL identifying the publication in the public portal. please follow below link for the End User Agreement:

www.umlib.nl/taverne-license

Take down policy

If you believe that this document breaches copyright please contact us at:

repository@maastrichtuniversity.nl

providing details and we will investigate your claim.
}

Copyright and moral rights for the publications made accessible in the public portal are retained by the authors and/or other copyright owners and it is a condition of accessing publications that users recognise and abide by the legal requirements associated with these

- Users may download and print one copy of any publication from the public portal for the purpose of private study or research.

- You may not further distribute the material or use it for any profit-making activity or commercial gain

If the publication is distributed under the terms of Article $25 \mathrm{fa}$ of the Dutch Copyright Act, indicated by the "Taverne" license above, 


\section{Do Older Workers Have More Trouble Using}

a Computer Than Younger Workers?

ROA-RM-2002/1E

Lex Borghans and Bas ter Weel

\section{Research Centre for Education and the Labour Market}

Faculty of Economics and Business Administration

Maastricht University

Maastricht, February 2002 
ISBN 90-5321-339-2

Sec02.030.wpd 


\section{Contents}

Page

Acknowledgements

Abstract iii

1 Introduction 1

2 Conceptualizing the computerization of the labor market 4

3 Data 7

4 Computer use 12

4.1 The determinants of computer use 12

4.2 The relationship between wages and computer use $\quad 17$

4.3 The relationship between tasks and computer use $\quad 20$

$\begin{array}{ll}4.4 \text { Alternative explanations } & 20\end{array}$

5 Computer skills and wages 23

5.1 Explaining computer skills 23

5.2 The returns of computer skills 26

6 Concluding remarks $\quad 28$

$\begin{array}{ll}\text { References } & 29\end{array}$ 



\section{Acknowledgements}

We would like to thank Eric Gould, Andries de Grip, Hugo Hollanders, Erik de Regt, Jos Sanders, Bruce Weinberg, Finis Welch and the participants of the International Conference on Understanding Skills Obsolescence in Maastricht for useful comments on an earlier draft of this paper, Nic van Hal for research assistance and the Netherlands Organization for Scientific Research (NWO) for financial support. 


\begin{abstract}
Technological change is often perceived to harm the position of the incumbent workforce compared to new entrants. Particularly the labor-market position of older workers, who are thought to have lower abilities or incentives to acquire new skills, might be deteriorated by the arrival of new technologies. Computers are a major example of such a new technology. A lack of skills might hamper computerization of the jobs of older workers and decrease the value of their existing skills. Several authors have shown however that the age pattern of computer use does not seem to fit in this view and argued that the relationship between age, computer use and skills is more complex. This paper examines the computer use of older workers from the perspective that the availability of skills is not the only factor relevant for the decision to invest in computers. Using British data, estimates are presented showing that computer use does not depend on age when taking into account wage costs and the tasks to be performed at work. It does turn out that older workers embody less computer skills than younger workers, but the main distinction lies between the 20-29 year old workers and the others. Investigating the value of computer skills reveals that these skills do not seem to yield labor-market returns and the relative lack of computer skills is unlikely to negatively affect the wages of older workers. Hence, the analysis does not find support for the concern about older workers not being able to cope with computers.
\end{abstract}

Keywords: Wage Differentials by Skill; Computer Use and Skill; Skills Obsolescence JEL Classification: J30; J31 


\section{Introduction}

The digitization of the world as a result of the introduction of computers, chips, and information and communication technology, has been the most dramatic and important technological development of the past few decades. At the time of the introduction of the computer during the 1960s and the emergence of automation in the 1970s, the widespread use of PCs, the emergence of the Internet in the 1980s and 1990s, and the current innovations in the field of (mobile) telecommunication, there has been fear that some groups of workers would lose their jobs, creating a (digital) division of society. ${ }^{1}$

Much of the recent research on how computerization changes skill demand has been initiated by Krueger (1993) and focuses on computer use and wages. The results from this literature suggest that higher-skilled workers use computers more often and earn considerably higher wages because of applying their computer skills. Other work has analysed the complementarity between skilled workers and computers. Levy and Murnane (1996) and Autor, Levy and Murnane (2001) suggest that computerization has led to an increased demand for higher-skilled workers because workers who are able to carry out certain non-routine tasks benefit more than others from the support of computers in routine tasks. $^{2}$

Particular focus has been addressed to older workers because it is inferred that they often have trouble in understanding and adapting to the changing configuration of work when a computer is introduced. ${ }^{3}$ This might be due to the fact that computers seem to alter skill

1. See e.g., Braverman (1974) and Freeman and Soete (1994) for an overview. As it is easier to automate simple work, initially it was expected that the lower-educated would be the ones to suffer most from the rise of the computer at the workplace. Spenner (1985) suggests that the demand for labor would increasingly show a U-shaped pattern. On the one hand, demand for higher-skilled labor would hardly be affected by computerization; the advent of the computer even demands more higher-skilled experts who develop computers, operate them and write programs, while on the other hand, the work of the lower-skilled would become simpler. They would only need to press the button to switch the machine on and watch whether everything works properly. Although the fear for a digital divide remained, from the 1980s to the 1990s the focus shifted form the erosion of low-skilled work to the increasing skill requirements due to the introduction of computers.

2. The theoretical literature discussing the changing skill requirements as a result of rapid technological change related to the importance of skills includes papers by Aghion, Howitt and Violante (1998), Caselli (1999), Lloyd-Ellis (1999), Ahituv and Zeira (2001), Gould, Moav and Weinberg (2001), Violante (2002), Aghion (2002) and Borghans en Ter Weel (2002b).

3. For example, in the United States the Committee for Economic Development (1999) wrote a voluminous report titled "New opportunities for older workers". With respect to computer-related training for older workers they conclude that "the value of age-segregated classrooms may be greatest in computer-related training. Younger trainees generally possess more background knowledge that can aid in learning new applications, while older trainees are more likely to be starting from scratch. Mixing the two is likely to frustrate the younger trainees, who must move at a slower pace, and intimidate the older ones, who may feel overwhelmed." (p. 42). Furthermore, Microsoft has launched the Microsoft Senior Initiative to increase access and provide computer and Internet literacy to seniors; SeniorNet provides older adults access to computer technology to enhance their lives and enable them to share their knowledge; and Computer $U$ sets up 
requirements. Since older workers have skills of an older vintage, they will probably suffer more from technology shocks relative to younger workers whose skills are of a more recent vintage. In addition, older workers are argued to have lower learning capabilities than younger workers. Therefore, they will have more trouble in learning how to use computer equipment and might try to avoid work in which computers are used. Furthermore, the introduction of new technologies might demand additional training. ${ }^{4}$ The incentive to participate in such training programs will be lower for both the older workers themselves and the employer because there is fewer time during which the returns to the training investment could be captured, while the opportunity costs of this investment are on average higher due to the higher salary of older workers. The introduction of new technologies might therefore lower the older workers' wages, increase unemployment and induce early retirement because employment and earnings seem to become less secure. ${ }^{5}$

From this perspective one might expect computer use to be highly concentrated among younger workers. As has already been noticed by Friedberg (2001) and Weinberg (2001) this does not turn out to be the case. Empirical evidence concerning the relationship between computer use and age suggests that computer use is surprisingly flat over age groups and that the most frequent users are in the age groups 30-49 years old. Both younger and older workers use computers at work less frequently than this middle-aged group.

Interpreting these data from a skill perspective, Weinberg (2001) argues that experience and age might both stimulate and hamper computer use. From an investigation of computer adoption in the United States between 1970 and 1997 he concludes that on the one hand the part of human capital formed by experience is complementary to computer use, which seems to explain the difference in use between middle-aged and young workers. On the other hand, he observes that the ability to learn to use a computer decreases with age, which is consistent with lower computer use among older workers. Friedberg (2001) argues that the rather flat pattern of computer use over the life cycle suggests that the ability to

franchised computer training centers for older adults.

4. Bartel and Sicherman (1993) consider in this respect the retirement decision of older workers. They observe two opposing effects. First, they find a direct positive effect of technological change on the amount of on-the-job training, which delays the retirement decision of older workers. Second, they obtain a more indirect effect of technological change that suggests that human capital depreciates faster as a result of the introduction of new technologies. The former effect is more likely in the case of gradual technological change, whereas the latter is observed particularly when an unexpected increase in the rate of technological change is observed. This picture is consistent with the estimates of Allen (2001), who observes that wage growth of older workers is much higher in R\&D-intensive industries than in industries with little R\&D activity. In contrast, Peracchi and Welch (1994) and Ahituv and Zeira (2001) observe a decline in laborparticipation rates of older men and argue that these workers have been pushed out of the labor market as a result of technological change.

5. The decision to retire earlier because of a lack of skills seems to be consistent with the findings of Juhn (1992), who finds that particularly lower-educated workers have retired earlier in the most recent period. Farber (1996) finds for the United States that the overall rate of job loss is up somewhat in the 1990s. This increase in job loss is larger for older workers, but younger and less-educated workers continue to have the highest rates of job loss. 
adopt computers is the same for all workers. She argues that lower computer use among older workers results from their nearing retirement: for the oldest workers investing in computer skills is not worthwhile anymore, given the short period to recover the costs. Others have argued that problems to cope with computers adequately, might force older workers to leave employment and push them into early retirement or unemployment (e.g., Bartel and Sicherman, 1993, Pecchari and Welch, 1994 and Ahituv and Zeira, 2001). Computer use as a percentage of the working population might therefore provide a biased picture about what is actually going on. Finally, Borghans and Ter Weel (2001) and (2002a) show that computer use does not depend solely on the ability to work effectively with a computer. In general, an employee adopts a computer if the benefits of carrying out the tasks using a computer exceed the costs. Besides skills, the availability of computer applications to support the tasks of a worker, the cost of computer equipment, software and technical assistance and support, and the reduction in wage costs in comparison with the costs to operate and maintain a computer (system) is likely to influence the investment decision.

This paper elaborates on the research stream concerning the skill content of technological change by studying whether older workers have more trouble using computers than their younger colleagues. To do so, the following three items are addressed: (i) the incidence of computer use among older workers, (ii) their computer skills, and (iii) the effects of computerization on their labor-market position in terms of wages. The analysis adds a new perspective both to the existing literature on the computerization of the labor market and to the position of older workers on a labor market subject to rapid technological change. We analyse the position of older workers on the British labor market in the 1990s using data from the 1997 Skills Survey of the Employed British Workforce. These data include direct measures of computer skills and detailed information about the tasks workers have to carry out in their jobs. In contrast, previous studies on the computerization of the labor market did not use data on computer skills needed at work but used (dummy variables on) computer use, which only allowed for an indirect analysis of the relationship between computer use and skills. We start by analysing who uses a computer at work. To explain the age pattern of computer use, we argue that a firm invests only in computer equipment when it is worthwhile and show that, after controlling for the tasks to be performed and the wage costs that can be saved, no separate age effect seems to exist. Second, we investigate computer skills for the different age groups and find that older workers embody less computer skills than younger workers. This observation turns out to be mainly a gap between the youngest workers (2029 ) and the other age groups and does not seem to affect the oldest workers (50-60) specifically. Experience with using a computer and the frequency of computer use at work seem to be the main determinants of computer skills; after controlling for these variables younger workers remain to embody more computer skills, however. Finally, we investigate the effects of computer skills on wages and obtain that older workers are not affected in terms of wages by their relatively lower computer skills. Our results suggest that it is not likely that computer skills have a notable labor-market value and that the concern about the older workers not being able to work in the computer age seems to be ill-founded. 
The paper proceeds as follows. In Section 2 the theoretical framework used to empirically analyse the computerization of the labor market is developed. In Section 3 the data and skill measures are explored and preliminary statistics are reported. Section 4 addresses the determinants of computer use. Section 5 focuses on computer skills and investigates the determinants of computer skills and the relation between computer skills and wages. Section 6 concludes.

\section{Conceptualizing the computerization of the labor market}

An essential characteristic of the computer is that it supports workers in the activities they are involved in during working time. The equipment is somewhere near the individual's workplace: the personal computer with access to the Internet is on one's desk, the mobile phone is in one's bag, and the computerized cash register is on the counter. In general the computer supports a worker by taking over some tasks, which leads to a more efficient mode of production without taking over all work rendering the worker superfluous. To determine the influence of computers on the way people work and to explain when a computer will be adopted to support certain activities, it is useful to take a closer look at the way in which computer equipment is applied at the workplace. For this it is important to distinguish three different kinds of activities in a job. First, there are tasks a worker not using a computer has to carry out, but which are taken over by a computer once introduced. Second, other tasks remain to be fulfilled by the worker after the introduction of a computer. Third, after the introduction of a computer a set of new tasks might emerge related to operating the computer. In most cases these tasks are highly interrelated. For example, thinking about the contents of a text and writing it down might be combined activities, but if the actual writing activity using a typewriter is substituted for a computer with wordprocessing software, the thinking part of the work remains essential to come up with a consistent text. ${ }^{6}$ Some have stressed that a computer might also change the activities that are not taken over by the computer. Since processing information and communicating become cheaper, firms might change the organizational structure, the characteristics of the product and the way it is produced to take advantage of these new possibilities. These changes are likely to affect the non-computerized part of the work as well. ${ }^{7}$

Thinking about a job as a set of tasks that have to be performed enables us to conceptualize how the configuration of the job (and the labor market) changes after computers are introduced. Of course, each task a worker has to perform requires some part of the working time and the time needed to fulfill a certain job aspect depends on the skills of the worker involved. Some skills might be related to the performance of all tasks, while other, more

6. Although the nature of and the required skills for the tasks may differ greatly, we assume that the interrelationship of the activities makes it impossible to separate the tasks into two different jobs, which would have enabled the appointment of two individuals, each of whom would be best qualified for one of the tasks.

7. See e.g., Lindbeck and Snower (2000), Caroli and Van Reenen (2001), Garicano (2001) and Bresnahan, Brynjolfsson and Hitt (2002) for such arguments. 
specific skills are likely to influence the time needed for the performance of a specific task only. For example, workers with more years of schooling (and hence higher skills) might perform all tasks faster than workers with less years of schooling (both before and after computerization), while a waitress with high communication skills might be excellent in dealing with clients, but not perform better in handling orders before or after computerization.

From this conceptualization of the job, the introduction of the computer can be viewed upon as a firm's decision, which depends on the costs and benefits involved. This decision is based on a break-even point at which the firm's profits are the same whether or not some part of the job is performed using a computer. A company will only decide to adopt computers if the costs involved match the time that can be gained. Apart from considering the costs of buying and maintaining a computer and perhaps initial training to provide the workers with the skills needed to operate the system, the decision is based on three components, which might be related to a worker's productivity gain from using a computer: (i) the importance of the tasks that can be computerized within a job, (ii) the skills of the typical worker involved, and (iii) the wage the employer has to pay the worker or equivalently the wage costs the employer is able to save when production becomes more efficient.

First, it seems to be rather trivial that computer use requires a job in which tasks can be computerized: what is the point of assigning a computer to a lumberjack and measuring the labor market impact? However, most jobs involve routine and repetitive tasks, which could in principal be subject to computerization. For example, an optician's job involves making and selling (sun)glasses. It is important for the optician to repair, cut and assemble the glasses with the utmost care. Additionally, she must be able to address the customers' wishes with accuracy and patience in order to be able to fulfil their demands and advise them on a good pair of glasses. Similarly, a chief editor has to keep track of and process data that dictate the contents of a newspaper, magazine, or radio or television program. At the same time, it is important that he has the capacities to manage and inspire people to do their jobs well and cooperate as an editing team. In the case of the optician manufacturing and repairing glasses is a routine procedure involving a cognitive and manual procedure, which could be performed by computer equipment probably more efficiently and adequately. However, advising clients is complicated and probably not subject to computerization. The chief editor could obviously use the Internet to find information more efficiently and faster but managing an editing team is not a task easily subject to computerization because it is likely to involve non-routine problem solving and interactive tasks. ${ }^{8}$

Second, time gained in the production process, as a result of computerization, is translated into a productivity increase and constitutes savings on labor costs because more output can be produced using the same labor input. This time gain depends on the specific character of

8. Naturally, the boundary between what can be computerized at a given moment in time and what cannot, is vague. Huge investments and the use of a large number of programmers might ensure computerization of tasks that cannot usually be performed by making use of a computer. However, for the sake of the arguments we assume that the boundary between what can be computerized and what cannot, is a clear one. 
the tasks to be performed, but also on the skill level of the worker concerned. The part of the time gain resulting from specific tasks that have to be performed, is likely to reflect the development of new and more efficient applications, software and hardware. ${ }^{9}$ With respect to skills it is likely that if a particular worker is more efficient in performing the job after computerization, this worker benefits more from computer use than another worker who is less efficient or skilled to do so. To see this, note that when the computer is introduced, the time needed to produce one unit of production (i) is reduced by the time needed to perform the computerized tasks, (ii) is increased by the time needed to operate the computer, and (iii) might be modified due to changes in the non-computerized tasks. From a skill perspective, computer use is therefore likely to be most efficient for workers with relatively low skills to perform the tasks subject to computerization and relatively high skills for operating the computer and non-computerized tasks. This relation between the time gain resulting from computerization and a worker's skill level can be defined as the skill bias of the adoption of a new technology because the skills might either be related to the carrying out of the computerized tasks or the other tasks, which might be more advantageous to relatively skilled workers compared to unskilled workers.

However, from this skill argument some observations can be drawn, which question its validity. First, if a relatively skilled worker has a higher pace of work for every task, there seems to be no reason to expect computer adoption among these workers from a skill perspective, since it is the relative productivity gain that matters. Second, workers with high abilities to bring to completion the non-computerized (and often the non-routine cognitive) part of the job, both before and after the introduction of the computer, do not have a higher probability to use the computer, since it leaves the time requirements to carry out the noncomputerized tasks unaffected. Finally, even very large differences in computer skills between people might have only a very moderate impact on computerization if the time needed for the computerized (and often routinized) part of the work is marginal compared to the time needed for the other tasks.

Finally, the benefits from the amount of time saved by a computer are also determined by the level of the wages of the employee(s) involved. A firm paying on average higher wages than another firm is likely to be more inclined to implement computers because it can save relatively more on wage costs: if wages are high, given the tasks to be computerized and the relative skills of the workforce, a computer will be worthwhile because it induces a more efficient production process. This argument is confirmed by findings of Doms, Dunne and Troske (1997) based on firm level panel data, Entorf and Kramarz (1997) based on a panel of individuals and Chennells and Van Reenen (1997) based on IV-estimates in which wages and choice of technology are estimated simultaneously, who indeed find that firms paying higher wages adopt computers earlier than other firms. This reveals that wages are likely to

9. Greenwood and Yorukoglu (1997) provide figures showing that the price of computer equipment has fallen dramatically since the mid-1970s and that the share of IT investment in total capital investment has risen from about 10 percent in 1970 to some 40 percent in 1990. Of course, this fall in the price of computers has led to lower costs for employers to adopt computers and is likely to have contributed to its diffusion. 
be a main determinant of computer use, which suggests that computer use does not lead to a higher wage but that a higher wage increases the probability to use a computer. This observation is consistent with the results of many empirical studies on the computerization of the labor market observing that computer users earn higher wages (e.g., Krueger, 1993). These studies mainly predict higher wages as a result of using a computer, whereas this result suggests that the causality is reversed.

The decision to introduce a computer will depend on these benefits of introduction compared to the costs of a computer. Due to the decreasing costs of computer hardware and software adoption has increased. In general the costs of computer introduction will be the same for all workers. However, since there also might be costs for initial training when a computer is introduced, workers who will stay in their job for only a short while, will face relatively higher costs than others who might profit for a longer period from these skills. Although skills might explain the pattern of computer use, the framework put forward here suggests that (high)wage arguments are also likely to explain the pattern that higher-skilled (and higher-paid) workers more frequently use computers and that within each level of education computer users earn higher wages.

This framework conceptualizing the computerization of the labor market forms the basis for the empirical analysis in the remainder of this paper. The paper proceeds by first discussing the data and providing some preliminary figures and then reporting the estimation results.

\section{Data}

The data utilized in this paper have been collected in a survey, conducted in the first half of 1997, called the Skills Survey of the Employed British Workforce. The survey includes a relatively small, but representative, number of workers $(2,467)$ from Britain aged 20-60. Participants were asked several dozens of questions on their labor-market situation during face-to-face interviews to obtain information on various aspects of their jobs including qualifications, responsibilities, the importance and ability to carry out certain tasks at work, and training.

Of particular interest for the purpose of the present paper are the detailed questions on the use of computers at work. Table 1 summarizes the incidence of using a computer at work for different categories of workers in Britain in 1997 and a similar tabulation for computer use in Britain in 1985 and 1990 and comparable years for Germany and the United States. Computer use in the mid-1980s is lower in Germany and Britain than in the United States. In the early 1990s the gap between the USA and Britain and Germany has further increased, but in 1997 the fraction of workers using computers at work in Germany and Britain has passed the U.S. level of utilization. Differences in these figures might of course be related to 
Table 1

Percentage of workers in age, educational level and gender categories who use a computer at work in Germany, Britain and the United States

\begin{tabular}{|c|c|c|c|c|c|c|c|c|c|}
\hline \multirow[b]{2}{*}{ Group } & \multicolumn{3}{|c|}{ Germany } & \multicolumn{3}{|c|}{ Britain } & \multicolumn{3}{|c|}{ United States } \\
\hline & 1985 & 1992 & 1997 & 1985 & 1990 & 1997 & 1984 & 1993 & 1997 \\
\hline All workers & 18.7 & 35.9 & 58.5 & 19.3 & 27.8 & 69.2 & 24.3 & 45.1 & 52.5 \\
\hline \multicolumn{10}{|c|}{ Age } \\
\hline Age 20-29 & 18.0 & 34.9 & 63.6 & 21.2 & 33.9 & 67.8 & 24.8 & 41.6 & 47.8 \\
\hline Age $30-39$ & 22.2 & 40.8 & 62.6 & 24.0 & 29.6 & 71.6 & 27.9 & 47.8 & 54.3 \\
\hline Age $40-49$ & 18.7 & 38.9 & 64.4 & 13.7 & 29.6 & 71.9 & 23.2 & 48.1 & 55.5 \\
\hline Age $50-60$ & 13.1 & 27.8 & 45.6 & 17.1 & 17.3 & 63.0 & 18.4 & 40.2 & 50.6 \\
\hline \multicolumn{10}{|c|}{ Educational level } \\
\hline$<$ High school & 4.3 & 9.9 & 40.5 & 12.0 & 19.2 & 40.2 & 5.1 & 10.4 & 12.6 \\
\hline High school & 18.3 & 32.7 & 55.4 & 28.2 & 35.9 & 55.1 & 19.2 & 34.6 & 36.9 \\
\hline Some college & 24.8 & 48.4 & 82.0 & 31.5 & 41.4 & 75.1 & 30.6 & 53.1 & 53.2 \\
\hline College & 30.5 & 61.6 & 82.2 & 45.9 & 53.8 & 95.5 & 42.4 & 70.2 & 71.2 \\
\hline \multicolumn{10}{|c|}{ Gender } \\
\hline Men & 18.5 & 36.4 & 58.3 & 24.1 & 30.4 & 69.2 & 21.6 & 41.1 & 43.6 \\
\hline Women & 18.5 & 33.5 & 58.8 & 14.9 & 25.7 & 69.1 & 29.6 & 53.2 & 55.6 \\
\hline
\end{tabular}

Note: Data about computer use in Germany refers to the Länder of the former West Germany only. For 1985 and 1992 data are taken from the German Qualification and Career Survey. For 1997 the German Social Economic Panel (GSOEP) has been used. Information about Britain stems from the British Social Attitudes Survey for 1985 and 1990 and the Skills Survey of the Employed British Workforce for 1997. Data on computer use in the

United Stated are based on the October Supplements of the Current Population Survey. 
different wordings of the questions in the surveys, but comparisons with other sources of information about computer use suggest that these effects are small. The most important message from table 1 is that although computer use at work is increasing over time, the patterns of use among various labor-market groups are very similar in relative terms. In all three countries computers are used predominantly by the higher-educated workers. In contrast to what is often expected, in all years and countries included in the table, the highest rate of computer use is not found in the youngest age group (20-29): workers in the age group 30-39 or 40-49 are in all cases except one the most frequent users.

The skills demanded by different jobs using computers and the tasks to be performed making use of computers vary enormously. To capture this diversity, the questionnaire distinguishes between the importance, level of sophistication and effectiveness of computer use.

With regard to the importance of computer use the following question has been asked: "In your job, how important is using a computer, PC, or other types of computerized equipment?". The response scale offered is the following: "essential", "very important", "fairly important", "not very important", and "not at all important". 10

With respect to the level of sophistication of computer use the following question has been asked: "Which of the following best describes your use of computers or computerized equipment in your job?". The answers are divided into four different levels of sophistication at which computers are being occupied. "Simple" use indicates "straightforward use, e.g., using a computer for straightforward routine procedures such as printing out an invoice in a shop". "Moderate" use means "e.g., using a computer for word processing and/or spreadsheets or communicating with others by email". "Complex" use is defined as "e.g., using a computer for analyzing information of design, including use of computer-aided design or statistical analysis packages". Finally, "advanced" use is described as "e.g., using a computer syntax and/or formulae for programming and developing software".

The effectiveness of computer use is measured by the answers to the following question: "When your job involves using a computer, PC or other type of computerized equipment, are you able to do this effectively?". Five possible answers were offered: "always", "nearly always", "often", "sometimes" and "hardly ever". ${ }^{11}$ The question used to measure the effectiveness of computer use to approximate computer skills has been subject of substantial debate among economists, psychologists and sociologists, especially in the literature regarding the importance of language skills. Borghans and Ter Weel (2002c) explore and test the consistency of the skill measure extensively and show that this approximation for computer skills can be used because (i) comparing the estimation results

10. The answer "not at all important" is reported in the data when workers do not use a computer at work. This answer has been given by 30.8 percent of the sample population.

11. Note that the design of the questions in the survey is such that questions on the level of sophistication and effectiveness of computer use have not been asked to people who indicate that they do not use a computer at work. 
for the effectiveness of computer use with other measures from the same survey yields estimates in line with a priori expectations: workers grade themselves lower with regard to skills and tasks viewed upon as relatively difficult, such as analytical thinking and carrying out complex and mathematical problems; (ii) there appears to be a strong and positive correlation between the importance, level of sophistication and effectiveness of computer use, which rejects the suspicion that the self-assessed computer skill measure is biased; and (iii) measuring other job items like analyzing problems, writing, reading and calculating reveal that higher levels of effectiveness yield higher returns. For convenience, the answers to the question on the effectiveness of computer use have been translated into the following manner. Respondents answering "always" to the question whether they are able to effectively use a computer, PC or other type of computerized equipment are labeled "very high" skilled. Answering "nearly always" makes a worker "high" skilled; "often" is "intermediate" skilled; "sometimes" is "low" skilled and "hardly ever" is "very low" skilled.

Table 2 reports the distribution of the answers to the three computer questions. The first panel reports information about the importance of computer use, the second and third report the distribution of answers of computer users on their level of sophistication and effectiveness of use. The numbers reported in the first column indicate that computer use is "essential" in almost one-third of all cases, and in 14.7 percent it is regarded as "very important". 11.5 percent of the respondents reported that computer use is "not very important". The level of sophistication of computer use reported is skewed towards "simple" and "moderate" tasks like routine procedures such as printing out an invoice in a shop and using a computer for word processing and/or spreadsheets or communicating with others by email. Only 3.4 percent of the respondents uses the computer at the "advanced" level. The third panel shows that more than half of the workers in the sample are relatively well able to use the computer effectively ("very high" or "high" computer skills). Among those who use a computer there seems to be a relatively small group of people who are often not able to carry out the computerized part of the job effectively: 10.2 percent of the total sample population answers have "low" or "very low" computer skills to use the computer effectively.

The remaining four columns in table 2 summarize the importance of computer use, the level of sophistication of computer use and computer skills for the four different age groups we distinguish in the empirical analysis. The numbers in the top panel show that the importance of computer use is highest in the age groups including workers aged 30-39 and 40-49. It also becomes clear that the importance is least for the oldest age group (50-60). The second panel reveals a negative correlation between age and the sophistication of computer use, since younger workers tend to utilize computers at a more advanced level than their older colleagues: 18.3 percent of the workers aged 20-29 uses a computer at a level higher than "moderate" compared to 17.1, 14.6 and 11.2 percent for workers aged 30-39, 40-49 and 5059 , respectively. Finally, the answers to the computer skills question are reported in the third panel of table 2. The main insight from this panel is that younger workers generally embody more computer skills than older workers, reinforcing the general feeling that younger workers seem to be more able to use a computer than older workers. Also interesting to note is that particularly the youngest workers possess the highest computer skills. Comparing the 
two highest levels of computer skills with one another reveals that 56.4 percent of the youngest workers (20-29) possesses at least "high" computer skills compared to 53.9, 53.2 and 41.5 percent for workers aged 30-39, 40-49 and 50-60. Looking at the group of workers having only "very low" computer skills we observe that more than twice as many workers aged 50-60 report to have "very low" computer skills compared to the youngest workers (2029).

Table 2

Percentage of computer using workers in Britain evaluating the importance of use, the level of sophistication of use and computer skills categorized by age

\begin{tabular}{|c|c|c|c|c|c|}
\hline \multicolumn{6}{|c|}{ The importance of computer use at work } \\
\hline \multirow{7}{*}{$\begin{array}{l}\text { 1. Essential } \\
\text { 2. Very important } \\
\text { 3. Fairly important } \\
\text { 4. Not very important } \\
\text { 5. No computer use }\end{array}$} & \multirow[t]{2}{*}{ Total } & \multicolumn{4}{|c|}{ Age } \\
\hline & & $20-29$ & $30-39$ & $40-49$ & $50-60$ \\
\hline & 30.3 & 32.2 & 33.5 & 29.2 & 24.3 \\
\hline & 14.7 & 11.8 & 14.3 & 18.4 & 13.7 \\
\hline & 12.7 & 12.8 & 12.2 & 14.0 & 11.6 \\
\hline & 11.5 & 11.0 & 11.6 & 10.3 & 13.3 \\
\hline & 30.8 & 32.2 & 28.4 & 28.1 & 37.0 \\
\hline \multicolumn{6}{|c|}{ The level of sophistication of computer use at work } \\
\hline & \multirow[t]{2}{*}{ Total } & \multicolumn{4}{|c|}{ Age } \\
\hline & & $20-29$ & $30-39$ & $40-49$ & $50-60$ \\
\hline 1. Advanced & 3.4 & 4.3 & 4.4 & 2.5 & 2.1 \\
\hline 2. Complex & 12.1 & 14.0 & 12.7 & 12.1 & 9.1 \\
\hline 3. Moderate & 26.1 & 25.4 & 25.9 & 29.2 & 23.3 \\
\hline 4. Simple & 27.6 & 23.3 & 27.1 & 25.8 & 26.4 \\
\hline 5. No computer use & 30.8 & 33.1 & 30.0 & 30.3 & 39.1 \\
\hline \multicolumn{6}{|c|}{ Computer skills } \\
\hline & \multirow[t]{2}{*}{ Total } & \multicolumn{4}{|c|}{ Age } \\
\hline & & $20-29$ & $30-39$ & $40-49$ & $50-60$ \\
\hline 1. Very high & 27.0 & 34.7 & 27.9 & 23.5 & 22.0 \\
\hline 2. High & 24.8 & 21.7 & 26.0 & 29.7 & 19.5 \\
\hline 3. Intermediate & 7.2 & 4.7 & 8.0 & 7.2 & 8.5 \\
\hline 4. Low & 5.7 & 3.7 & 5.7 & 7.0 & 6.0 \\
\hline 5. Very low & 4.5 & 3.1 & 3.7 & 4.4 & 6.7 \\
\hline 6. No computer use & 30.8 & 32.2 & 28.7 & 28.3 & 37.2 \\
\hline
\end{tabular}

Note: The data are taken from the Skills Survey of the Employed British Workforce.

The overall pattern becoming apparent from the distribution of the answers to the questions related to the computerization of the job reported in table 2 suggests that workers in the age group 50-60 are less able to work with a computer than younger workers and use the computer at a less sophisticated level. In the next sections we further elaborate on these correlations by investigating in more detail the determinants of computer use in relation to age (Section 4) and the value of computer skills (Section 5). 


\section{Computer use}

\subsection{The determinants of computer use}

Table 1 presents figures from three countries showing that workers aged 30-49 use a computer more frequently than younger and older workers. An important question however is whether age itself (with the skills and experience related to it) explains this pattern, or whether other worker and job characteristics explain this particular age profile of computer use. In Section 2 we put forward that computer investments by firms are based on costbenefit considerations: as a computer increases the productivity in certain tasks, the benefits of computer use are most likely to depend on (i) the tasks the worker has to carry out, (ii) the skills of the worker to use the computer effectively, and (iii) the wage costs the firm has to incur. To determine the effect of skills on computer use we proxy the worker's skills by educational level, working experience, and age.

The main purpose of this analysis is to investigate whether computer use depends on age. To analyse the importance of age, we estimate the determinants of computer use. To do so the following equation has been estimated:

$$
\ln \left(\frac{P_{i}}{1-P_{i}}\right)=C_{i}+A_{i} \alpha+X_{i} \beta+T_{i} Y+\delta\left(\ln W_{i}\right)+\varepsilon_{i},
$$

where $P_{i}$ is the probability that the worker will use a computer, $C_{i}$ is a constant, $A_{i}$ is a vector of dummies indicating the age-classes 20-29, 30-39, 40-49, and 50-60, $X_{i}$ is a vector of personal characteristics including gender, education, experience etc., $T_{i}$ is a vector of ten specified job activities, ${ }^{12} \ln W_{i}$ is the log gross hourly wage, and $\varepsilon_{i}$ is an error term with the usual assumptions. The model has been analysed using a maximum likelihood estimation.

Table 3 reports the results of estimating equation (1). In the first column only a constant and the age classes are included, using workers aged 20-29 as the reference group. The coefficients confirm the previous observations because workers aged 30-49 have a higher probability of working with a computer than other workers. The probability to use a computer at work for older workers (50-60) in comparison with the 20-29 year old is slightly negative, though insignificant, which is also consistent with the figures provided in table 1 . These results seem to be consistent as well with the general conception that older workers use computers less often and employers assign older workers less often to jobs in which computers are used because of a lack of computer skills. In contrast, it seems hard to explain the lower levels of computer use for the younger workers using the same arguments.

12. These tasks are (1) listening carefully to colleagues, (2) physical strength, (3) physical stamina, (4) knowledge of the organization, (5) working out problems, (6) thinking of solutions, (7) reading written information, (8) reading long documents, (9) adding, subtracting or dividing, and (10) advanced calculations. The tasks included in the analyses are a subset of 36 tasks used in Borghans and Ter Weel (2002a). The tasks excluded here turned out to have no significant impact on computer use. 
Expanding the estimation by controlling for gender, experience, supervision, and level of education shows different results. The regression results presented in the second column of table 3 suggest that supervision and educational level are the main predictors of computer use. The results with respect to the level of education seem to be consistent with the explanation that higher-educated, and therefore more-skilled, workers have a higher probability to use a computer than their lower-educated, and therefore less-skilled, colleagues. The most noteworthy result reported in column (2) of table 3 is that, after controlling for gender and educational background, the age profile of computer use decreases monotonically with age. This suggests that the standard labor-market variables, like education, experience, and supervision determine computer use, which are typically variables pointing at an important role for higher-skilled workers in using computers.

The framework put forward in Section 2 suggests that wage costs might also be a determinant of computer use, since computers might enhance productivity and hence save on the wages to be paid by the employer. The main problem with estimating the regression equation is that wages and skills are likely to be highly correlated, while there is likely to be measurement error in the wage variable as well and part of a worker's skills might be unobserved directly, but nevertheless be reflected in the wage. Furthermore, there might be a concern of endogeneity of computer use influencing wages. If a substantial part of the skills are unobserved, part of the effect of skills on computer use will be absorbed by wages in the estimates. This causes an upward bias in the parameter for the wage effect and a downward bias in the skill parameters. If the main problem is the measurement error in the wage variable, the wage parameter will be downward biased while the skill parameters absorb this effect and will be upward biased. To estimate equation (1) we therefore use instrumental variables for the wage variable. Since it seems plausible to assume that variables related to unionization influence wages but do not interfere with skills and computer use directly, we use several variables related to unionization as instruments for wages in the estimation. In Britain, about 50 percent of the workers is covered by a union, the coverage is fairly equally spread over occupations and sectors and has a substantial effect on wages. For these three reasons the instruments provide an opportunity to investigate the direct link between wages and computer use from a statistical point of view. From an economic point of view, Borghans and Ter Weel (2002a) show empirical support for (i) unionization variables not influencing computer use directly; (ii) unionization is sufficiently uncorrelated with unobserved skill components; and not approximating for aspects of firms, which are more likely to adopt computers. Finally, econometrically it is shown that the criterion of Staiger and Stock (1997) that the $F$-value should be larger than 10 is met in all specifications, suggesting that the instruments are strong enough to avoid serious problems in the IV-regressions.

The results of the IV-regression are reported in the third column of table $3 .^{13}$ The coefficients reveal that gender and the log gross hourly wage seem to be the only significant predictors

13. To instrument the wage, we add to this model a linear equation explaining $\ln W_{i}$ with the same $A_{i}$ and $X_{i}$ and $T_{i}$ vectors plus union coverage. In equation (1) the wage has been replaced by the predicted wage from this equation. 
of computer use. Even variables pointing at an advantage for the higher-skilled workers, like education, experience and supervision, show up insignificantly now. ${ }^{14}$ Our reading of these regression results is the following. With regard to gender, it is likely that female workers gain more from the introduction of computers than male workers. This might be related to the fact that computers change work conditions and particularly de-emphasize physical strength, which favors female workers relatively more than male workers (e.g., Weinberg, 2000). ${ }^{15}$ With respect to wages being a main determinant of computer use, it is likely that employers assign high-wage workers to computers first because they can save most on wage costs. This is consistent with the framework developed in Section 2 and reverses the causality of the main arguments of studies who argue that computer use leads to a higher wage.

The results reported in column (3) also show that, after controlling for wage, the influence of age on computer use is monotonically decreasing, with significant parameters for both 40-49 and 50-60 year old workers, and the significant effect of education on computer use vanishes once wages have been included in the analyses. These findings are also consistent with the framework put forward in Section 2, suggesting that wage costs rather than skill considerations are likely to explain the decision of an employer to adopt computers. The results reported in column (4) support this argument because they show that exclusion of the educational level does not change the coefficients of the other parameters significantly.

Finally, information about the working tasks is used to investigate whether computer use is related to the performance of specific tasks. The results of this estimation are reported in the final column of table 3 . First, including these tasks substantially improves the explanatory power of the model. Second, gender and the log gross hourly wage again turn out to be significant determinants of computer use and tasks like listening, reading and writing, and calculating also seem to increase the likelihood of using a computer, whereas physical tasks seem to be negatively related to computer use. Third, the impact of age on computer use becomes insignificant, while the coefficient for the age group 40-49 and 50-60 further decreases suggesting that there is no significant age effect in the decision of employers to adopt computers.

14. Education and age only have an (insignificant) indirect effect through wages on computer use (e.g., Borghans and Ter Weel, 2002a).

15. The rather large effect of gender on the likelihood of using a computer is partly offset by a negative indirect effect of gender through wages on the likelihood of using computers. This is the result of female workers earning less than male workers. However, the results remain strong and significant. 


\begin{tabular}{|c|c|c|c|c|c|}
\hline & 1 & 2 & 3 & 4 & 5 \\
\hline $\begin{array}{l}\text { Age } \\
30-39 \\
40-49 \\
50-60\end{array}$ & $\begin{array}{r}.279(.126)^{\star} \\
.243(.134)^{\star} \\
-.151(.141)\end{array}$ & $\begin{array}{r}.291(.138)^{*} \\
-.251(.149)^{*} \\
-.012(.158)\end{array}$ & $\begin{array}{l}-.247(.249) \\
-.505(.302)^{\star} \\
-.539(.256)^{*}\end{array}$ & $\begin{array}{l}-.276(.235) \\
-.519(.271)^{*} \\
-.567(.223)^{*}\end{array}$ & $\begin{array}{l}-.130(.250) \\
-.244(.311) \\
-.283(.273)\end{array}$ \\
\hline Gender & & $.143(.102)$ & $.941(.260)^{* *}$ & $.783(.227)^{\star \star}$ & $.915(.285)^{\star \star}$ \\
\hline Supervisor & & $.937(.116)^{* *}$ & $.256(.248)$ & & $-.123(.217)$ \\
\hline $\begin{array}{l}\text { Education } \\
\text { NVQ } 1 \\
\text { NVQ } 2 \\
\text { NVQ } 3 \\
\text { Professional } \\
\text { University }\end{array}$ & & $\begin{array}{l}.591(.188)^{* *} \\
1.153(.134)^{* *} \\
1.439(.166)^{* *} \\
2.134(.219)^{* *} \\
3.236(.346)^{* *}\end{array}$ & $\begin{array}{r}.238(.312) \\
.366(.311) \\
.444(.383) \\
.487(.549) \\
1.068(.741)\end{array}$ & & $\begin{array}{r}.139(.295) \\
.273(.265) \\
.412(.329) \\
.392(.493) \\
1.107(.694)\end{array}$ \\
\hline Wage & & & $3.205(.911)^{* *}$ & $2.867(.618)^{* *}$ & $2.553(.949)^{* *}$ \\
\hline \multicolumn{6}{|l|}{ Tasks } \\
\hline Listening carefully to colleagues & & & & & $1.024(.329)^{* *}$ \\
\hline Physical strength & & & & & $-.714(.269)^{\star *}$ \\
\hline Physical stamina & & & & & $-.574(.274)^{* *}$ \\
\hline Knowledge of organization & & & & & $1.063(.371)^{* *}$ \\
\hline Working out problems & & & & & $.631(.386)$ \\
\hline Thinking of solutions & & & & & $-.535(.359)$ \\
\hline Reading written information & & & & & $.977(.365)^{* *}$ \\
\hline Reading long documents & & & & & $.750(.224)^{* *}$ \\
\hline
\end{tabular}




\begin{tabular}{|l|l|l|l|l|l|}
\hline $\begin{array}{l}\text { Table 3 (continued) } \\
\text { Logit estimation of the determinants of computer use in Britain (dependent variable: probability of computer use) }\end{array}$ \\
\hline & 1 & 2 & 3 & 4 & 5 \\
\hline Adding, subtracting or dividing & & & & $.935(.211)^{* *}$ \\
\hline Advanced calculations & & & & $1.112(.177)^{* *}$ \\
\hline Constant & $.678(.096)^{* *}$ & $-0.818(.162)^{* *}$ & $-5.426(1.329)^{* *}$ & $-4.448(1.120)^{* *}$ & $-7.923(1.403)^{* *}$ \\
\hline LL & -1362.62 & -1168.03 & -586.81 & -1014.29 & -194.56 \\
\hline
\end{tabular}

Note: The data are taken from the Skills Survey of the Employed British Workforce. * $=$ significant at the 5 percent level, and "* significant at the 1 percent level. All estimates are MLE. The age group 20-29 is taken as the reference group in the first row of the table. The gender dummy equals one if gender is female and zero if gender is male. The educational levels are defined according to the British classification from low to high (NVQ 1 to University) and no educational degree is taken as the reference group. The wage is the log of the gross hourly wage. The instrument used is union membership. 
Our overall reading of the regression results reported in table 3 is the following. First, the worker's wage along with some specific tasks and gender seem to be the main determinants of computer use. This result is consistent with the view that computers are introduced at the workplace to save on wage costs and to support particular activities. Second, the lack of significant results concerning the age variables in the full specification reported in column (5) suggests that age does not play an independent role in the decision to implement computers. Finally, educational level does not influence the likelihood of computer use significantly, which suggests that higher-educated and skilled workers have no particular advantage in using a computer.

\subsection{The relationship between wages and computer use}

The analysis has put forward two explanations for computer use at work, which are not related to skills, but which seem to contribute to an explanation of the age structure of computer use. These explanations for the use of computers are the wage and particular tasks. By means of a more detailed graphical analysis we will investigate the impact of these variables for the relationship between age and computer use.

\section{Figure 1}

Average wages and computer use in Britain by age

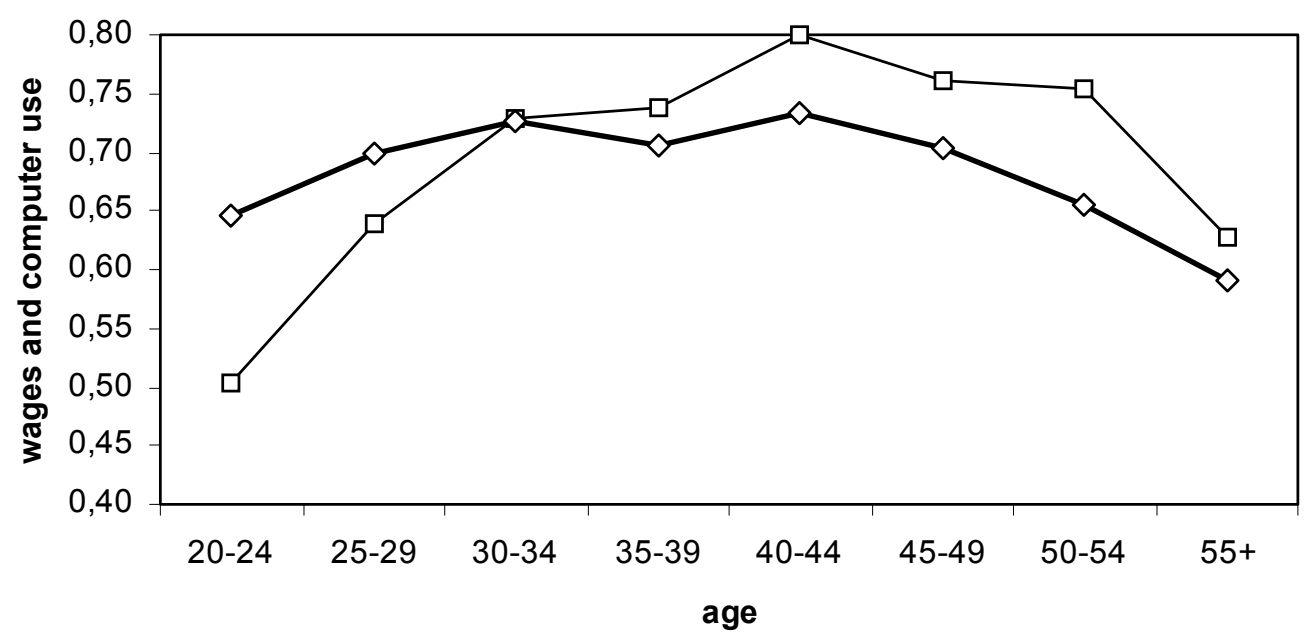

Note: The data are taken from the Skills Survey of the Employed British Workforce. The thin line with $\square$ marks represents wages, which are the average log gross hourly wages (divided by 10). The thick line with $\diamond$ marks represents the fraction of workers using a computer at work.

Figure 1 provides both the age profile of the (mean log gross hourly) wage and computer use. The figure illustrates that wages follow a similar inverted u-shaped pattern as computer use does. The dip in both curves at the age of 30-35 is due to the relative high participation of women in this age group. This additional group of women earns a relatively low wage and although on average women have a higher probability of computer use, this relatively low 
wage is likely to be causal to less computer use. ${ }^{16}$ The figure also suggests that, compared to the wage curve, computer use among young workers is relatively high and relatively low among older workers.

The framework of computer adoption suggests that not the mean wage but the fraction of workers above a certain "threshold" wage explains actual computer use. Figure 2 depicts fractions of workers above a certain threshold wage as a function of age. The graph shows lines with log threshold wages at 4.0, 4.5, 5.0, 5.5 and 6.0. The results from this exercise reveal that from this point of view the relationship between wages and computer use becomes more pronounced making the arguments in favor of wage costs determining computer use stronger.

\section{Figure 2}

Fraction of workers with wages above certain thresholds and computer use in Britain

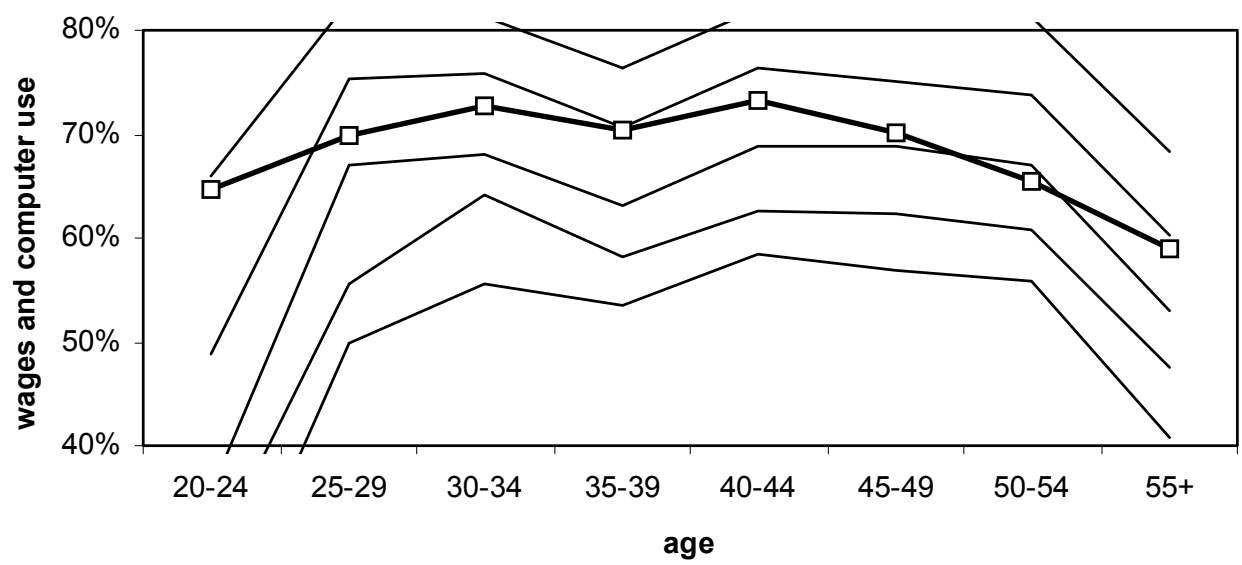

Note: The data are taken from the Skills Survey of the Employed British Workforce. The thick line with $\square$ marks represents the percentage computer use at work. The thin lines represent the fraction of workers with a log gross hourly wages of at least 6.0 (lowest line), 5.5, 5.0, 4.5 and 4.0 respectively.

Due to heterogeneity in other job characteristics and due to the effect of gender on computer use, the threshold wage is likely to vary for different workers. Figure 3 therefore provides a reconstruction of the predicted computer use per age group, assuming that for both sexes computer use in each wage category is constant. This means that the probability of computer use for each worker in the sample has been set equal to the fraction of computer use in the wage and gender category each individual worker is included in. Although some underestimation of computer use among younger workers and overestimation among older workers remains apparent, the lines in figure 3 reveal that wages and gender are able to explain the pattern of computer use quite well.

16. In other words, the indirect likelihood of computer use through wages is likely to be negative for women. 
Figure 3

Actual computer use and computer use predicted by wage and gender only

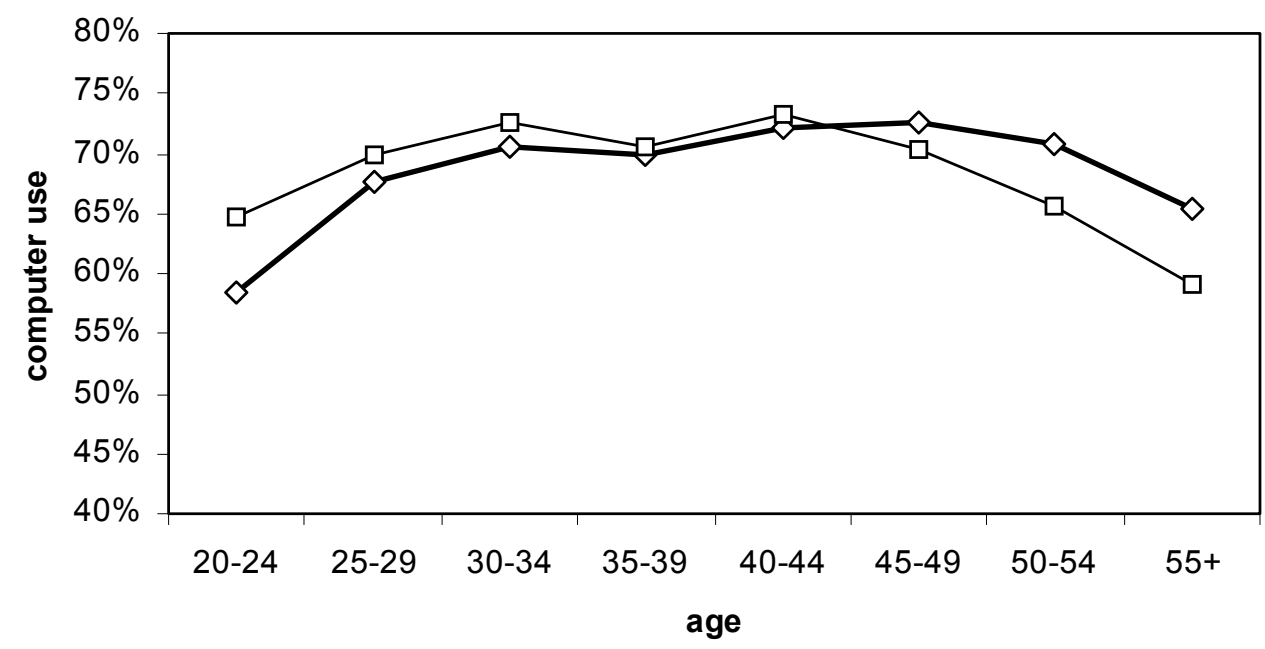

Note: The data are taken from the Skills Survey of the Employed British Workforce. The thin line with the $\square$ marks represents the percentage compute use at work. The thick line with $\diamond$ marks results from a calculation based on the assumption that the fraction of computer use in each gender-wage-group is equal for all ages.

Figure 4

Average wages of computer users and non computer users by age

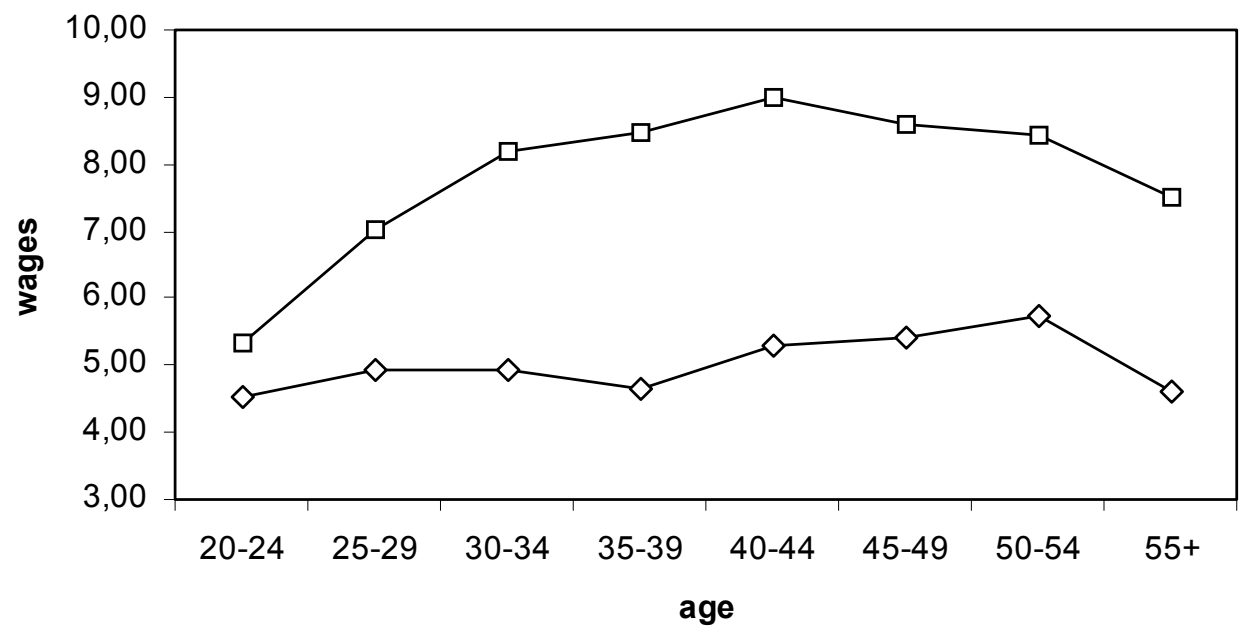

Note: The data are taken from the Skills Survey of the Employed British Workforce. The line with the $\diamond$ marks represents the average log gross hourly wage of workers not using a computer at work while the line with the $\square$ mark represents the wages of the workers with a computer.

While computer use could be explained by the level of wages in a certain job, many authors have investigated the reversed relationship by assuming that computer use leads to higher wages. If indeed computer use increases wages, the low average wages of older workers 
could also be a result of their low adoption rate. Figure 4 presents the average wages of both computer users and non-users. The graph reveals that the argument that computer use leads to higher wages is not very likely to hold, since both the wages of users and non-users have an inverted u-shaped form. The decreasing wage of older workers is therefore not likely to be the result of a shift between both groups.

\subsection{The relationship between tasks and computer use}

A second explanation for computer use is the performance of particular tasks at work. To show the impact of different tasks on the age profile of computer use, figure 5 presents the predictions of the regression reported in column (5) of table 3, in which all aspects except the tasks are kept constant. The figure shows that the different tasks workers have to fulfill, seem to contribute to the explanation of the relationship between age and computer use. Based on tasks only both the computer use of younger and older workers would be overpredicted to some extent, however.

Figure 5

Actual computer use and computer use predicted by tasks only

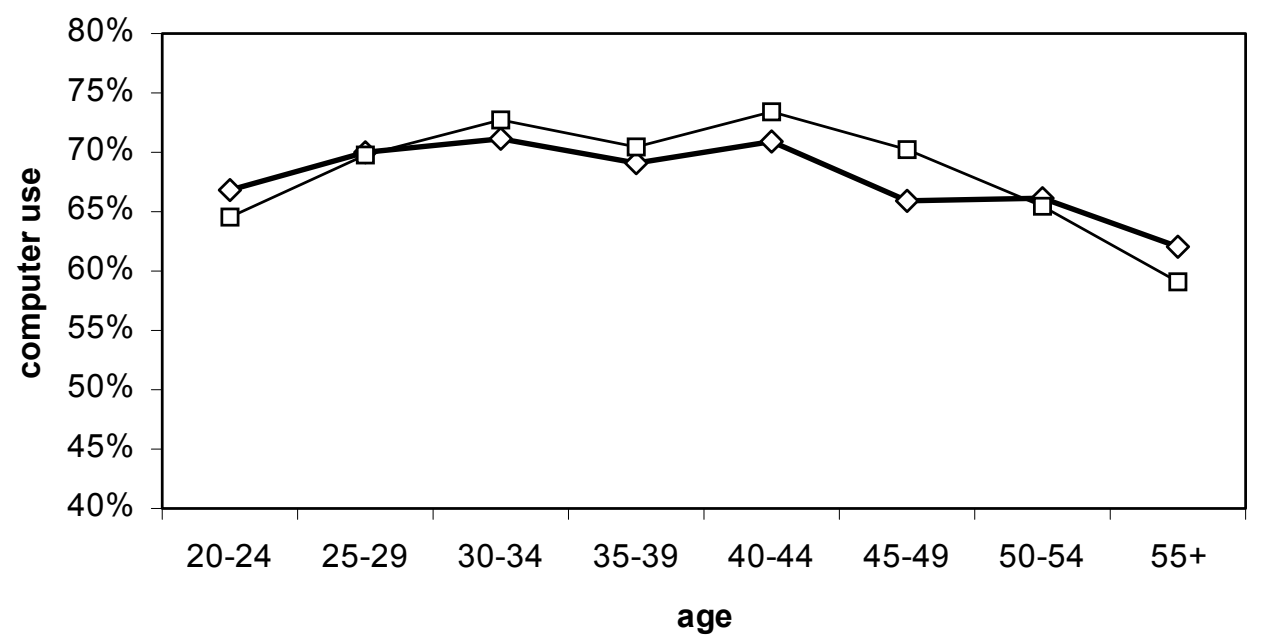

Note: The data are taken from the Skills Survey of the Employed British Workforce. The thin line with the $\square$ marks represents the percentage compute use at work. The thick line with $\diamond$ marks represents the predicted computer use form column (5) in table 3 , by keeping all variables except the tasks constant.

\subsection{Alternative explanations}

In the literature alternative explanations for the (non-)use of computers by older workers have been suggested. First, Ahituv and Zeira (2001) put forward that the inability to cope with new technologies might force older workers to leave employment, and either become unemployed or retire earlier. In that case computer use split by age groups would underestimate the effects of this technology on the labor-market position of older workers. 
Although the data only contain information about employed workers, a test of this hypothesis is to investigate the relationship between the fraction of older workers (50-60) in each occupational category and the degree of computerization in these occupational groups. Based on 74 2-digit occupations an OLS-regression weighted by the number of observations in each occupational group results in an insignificant coefficient of - .013 (.034) for computer use (standard error in brackets). In addition, figure 6 shows the absence of the relationship graphically. A similar investigation based on 2-digit industrial codes also provides a insignificant relationship between a sector's computer use and the fraction of workers aged 50-60 (-.025 (.061)).

Figure 6

Relationship between average computer use and fraction of older worker per occupation (2-digit)

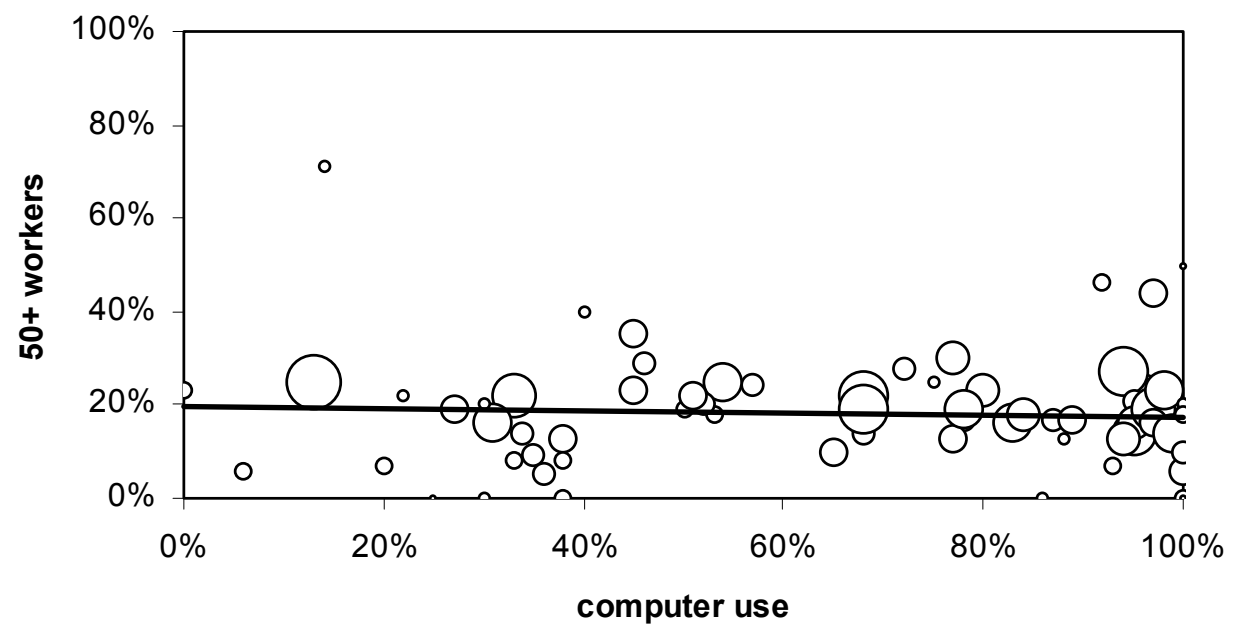

Note: The data are taken from the Skills Survey of the Employed British Workforce. For each 2digit occupational category a dot represents the relationship between the percentage computer use of all workers and the percentage workers with age 50 years or older. The size of the dots represents the number of observations in each occupation. The line results from weighted least squares estimation of the fraction of $50+$ workers as a function of computer use in the occupation.

Second, Friedberg (2001) argues that although the costs of acquiring computer skills might be constant in age, the benefits for older workers will be lower because they envisage their retirement within a short period of time. As put forward in Section 2 this argument suggests that the costs of introducing a computer is relatively high. This effect would imply that computer use among older workers is only lower than computer use among others if computers are introduced in the relevant sector or occupation recently. The change in computer use in the previous period should therefore be a good predictor of the computer use of older workers in comparison with others. table 4 reports the regression results of a weighted OLS-regression explaining the percentage computer use of older workers in each occupation or sector by the overall computer use in this occupation or sector and the change in computer use over the past five years. For Friedberg's arguments to hold, we would expect the coefficient on the change in computer use to be negative. Although the 
coefficients are negative in three of the four cases, they appear to be insignificant suggesting that the envisioning of retirement is not likely to be an important determinant of not using a computer.

\section{Table 4}

Relationship between computer use of older workers (50-60) and computer use of all workers and the recent change in computer use per occupation and sector of industry

\begin{tabular}{|l|c|c|c|c|}
\hline \multirow{2}{*}{} & \multicolumn{2}{|c|}{ occupation } & \multicolumn{2}{c|}{ sector of industry } \\
\cline { 2 - 5 } & $\begin{array}{c}\text { with } \\
\text { constant }\end{array}$ & without constant & $\begin{array}{c}\text { with } \\
\text { constant }\end{array}$ & without constant \\
\hline constant & $-.073(.046)$ & & $-.160(.091)$ & \\
\hline computer use & $1.027(.051)^{* *}$ & $.968(.035)^{* *}$ & $1.092(.105)^{* *}$ & $.944(.063)^{* *}$ \\
\hline$\Delta$ computer use & $-.034(.137)$ & $-.157(.113)$ & $.152(.253)$ & $-.106(.210)$ \\
\hline $\mathrm{R}^{2}$ adj. & .863 & .973 & .686 & .963 \\
\hline
\end{tabular}

Note: The data are taken from the Skills Survey of the Employed British Workforce.

Figure 7

Relationship between computer use and change in computer use for all workers and older workers per occupation

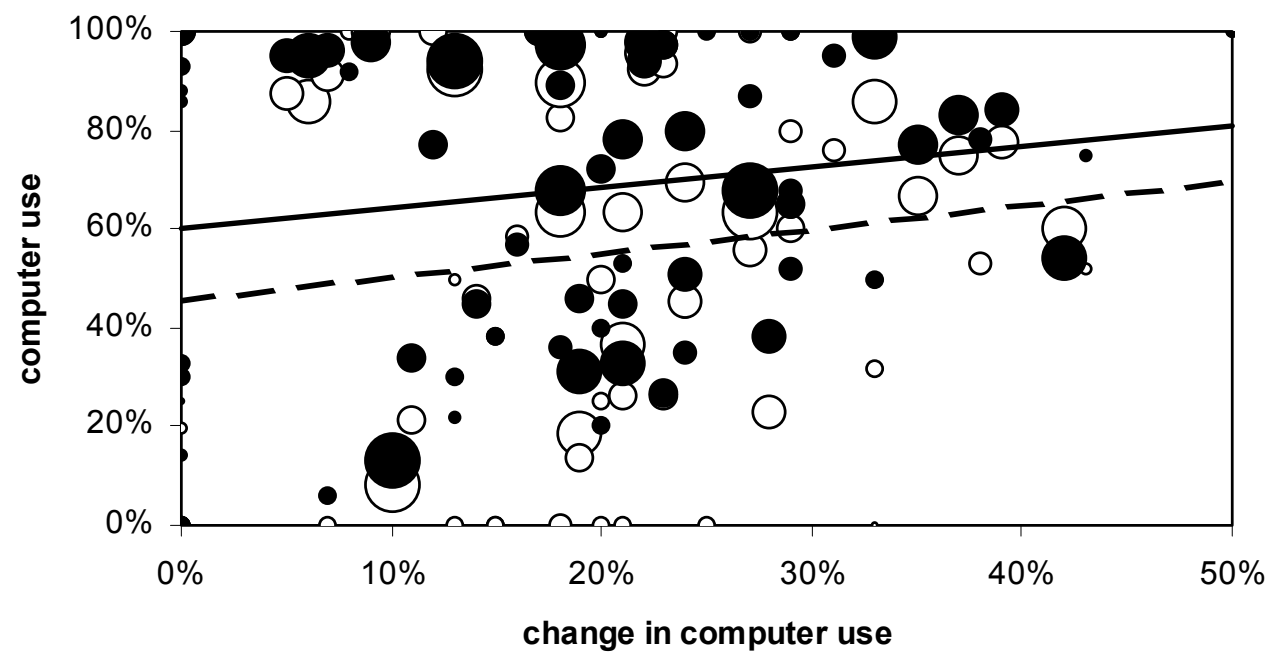

Note: The data are taken from the Skills Survey of the Employed British Workforce. For each 2digit occupational category a black dot represents the relationship between the percentage computer use of all workers and the change in computer use over the period 1992-1997. Open dots represent the same relationship for the computer use among 50+ workers only. The size of the dots represents the number of observations in each occupation. The solid line results from weighted least squares estimation of the percentage computer use as a function of change in computer use in the occupation. The marked line represents a similar regression for computer use among $50+$ workers.

Figure 7 shows the relationship between the change in computer use and the current computer use for both workers aged 50-60 and the labor force as a whole in the occupations 
distinguished. Although there is a relationship between recent change and current use, the slope of this relationship is basically the same for all workers. Introducing computers does not seem to affect older workers differently from younger workers.

\section{Computer skills and wages}

\subsection{Explaining computer skills}

Although the analyses in the previous section indicate that computer use is not directly related to age, older workers might have more trouble using a computer than younger workers. To investigate this, differences in the effectiveness of computer use between age groups are addressed. Table 5 reports the results from estimating the determinants of computer skills. The regression results reported in the first column take computer skills as the dependent variable and the age classes and gender as the independent ones. The results suggest a negative relationship between age and computer skills. Given that the youngest age group is the reference group, workers in the age class 50-60 have a probability of more than 40 percent to report computer skills one level lower than their youngest colleagues. Including educational levels in the regression does not seem to alter this picture, as reported in column (2). It is interesting to note that workers with higher levels of education report to possess significantly higher computer skills.

Since computer skills might be related to experience with using a computer and since we know from the analyses in the previous section that higher-educated workers (workers with a higher wage) use a computer more frequently, the effect of the educational level has to be disentangled from the experience with using a computer and the type of computer use. To investigate the hypothesis that older workers have more trouble using a computer, the following equations have been estimated:

$$
S_{i}=C_{i}+A_{i} \alpha+X \beta+\gamma L_{i, 97}+\delta L_{i, 92}+\varepsilon_{i}
$$

for the relationship between computer skills and the level of sophistication of use in 1997 $\left(L_{i, 97}\right)$ and in $1992\left(L_{i, 92}\right)$, and

$$
S_{i}=C_{i}+A_{i} \alpha+X \beta+\gamma I_{i, 97}+\delta I_{i, 92}+\varepsilon_{i}
$$

to determine the relationship between computer skills and the importance of computer use in both years $\left(I_{i, 97}\right.$ and $\left.I_{i, 92}\right)$. The results of these two estimations and a combination of both are reported in the remaining columns of table 5.

Column (3) presents estimation results including the level of sophistication of computer use. These results suggest a positive correlation between the level of sophistication of computer 


\begin{tabular}{|c|c|c|c|c|c|c|c|}
\hline \multicolumn{8}{|c|}{$\begin{array}{l}\text { Table } 5 \\
\text { Estimation of the level of computer skills of computer users (dependent variable: computer skills) }\end{array}$} \\
\hline & 1 & 2 & 3 & 4 & 5 & 6 & 7 \\
\hline $\begin{array}{l}\text { Age } \\
30-39 \\
40-49 \\
50-60\end{array}$ & $\begin{array}{l}-.194(.076)^{*} \\
-.303(.080)^{* *} \\
-.413(.089)^{* *}\end{array}$ & $\begin{array}{l}-.202(.076)^{* *} \\
-.295(.081)^{* *} \\
-.382(.091)^{* *}\end{array}$ & $\begin{array}{l}-.156(.071)^{*} \\
-.243(.075)^{*} \\
-.300(.084)^{* *}\end{array}$ & $\begin{array}{l}-.220(.071)^{* *} \\
-.335(.076)^{* *} \\
-.377(.084)^{* *}\end{array}$ & $\begin{array}{l}-.215(.065)^{* *} \\
-.303(.069)^{* *} \\
-.314(.077)^{* *}\end{array}$ & $\begin{array}{l}-.253(.065)^{* *} \\
-.351(.069)^{* *} \\
-.370(.077)^{* *}\end{array}$ & $\begin{array}{l}-.228(.064)^{* *} \\
-.323(.069)^{* *} \\
-.338(.076)^{* *}\end{array}$ \\
\hline Gender & $.056(.055)$ & $.064(.055)$ & $.132(.052)^{*}$ & $.139(.051)^{* *}$ & $-.070(.047)$ & $-.061(.047)$ & $-.020(.047)$ \\
\hline $\begin{array}{l}\text { Education } \\
\text { NVQ } 1 \\
\text { NVQ } 2 \\
\text { NVQ } 3 \\
\text { Profess. } \\
\text { University }\end{array}$ & & $\begin{array}{l}.239(.137) \\
.163(.097) \\
.224(.108)^{*} \\
.230(.109)^{*} \\
.379(.113)^{* *}\end{array}$ & $\begin{array}{r}.132(.127) \\
-.064(.091) \\
-.076(.102) \\
-.157(.104) \\
-.131(.109)\end{array}$ & $\begin{array}{r}.098(.126) \\
-.084(.090) \\
-.098(.101) \\
-.199(.103) \\
-.142(.108)\end{array}$ & $\begin{array}{l}.120(.116) \\
.038(.082) \\
.074(.092) \\
.091(.092) \\
.074(.096)\end{array}$ & $\begin{array}{r}.095(.115) \\
.016(.082) \\
-.027(.091) \\
.063(.092) \\
.047(.095)\end{array}$ & $\begin{array}{r}.075(.114) \\
-.047(.082) \\
-.102(.091) \\
-.054(.093) \\
-.099(.098)\end{array}$ \\
\hline \multicolumn{8}{|c|}{ Level of sophistication of computer use } \\
\hline Moderate & & & $.707(.060)^{* *}$ & $.651(.065)^{* *}$ & & & $.270(.058)^{* \star}$ \\
\hline Complex & & & $1.023(.076)^{* *}$ & $.922(.086)^{* *}$ & & & $.333(.076)^{* *}$ \\
\hline Advanced & & & $1.409(.124)^{* *}$ & $1.307(.163)^{* *}$ & & & $.579(.121)^{* *}$ \\
\hline \multicolumn{8}{|c|}{ Level of sophistication of computer use five years ago } \\
\hline Simple & & & & $.376(.064)^{* *}$ & & & \\
\hline Moderate & & & & $.330(.073)^{* *}$ & & & \\
\hline Complex & & & & $.367(.109)^{* *}$ & & & \\
\hline Advanced & & & & $.347(.202)^{* *}$ & & & \\
\hline \multicolumn{8}{|c|}{ Importance of computer use } \\
\hline Fairly imp. & & & & & $0.803(.081)^{* *}$ & $.748(.081)^{* \star}$ & $.667(.082)^{\star \star}$ \\
\hline
\end{tabular}




\begin{tabular}{|c|c|c|c|c|c|c|c|}
\hline \multicolumn{8}{|c|}{$\begin{array}{l}\text { Table } 5 \text { (continued) } \\
\text { Estimation of the level of computer skills of computer users (dependent variable: computer skills) }\end{array}$} \\
\hline & 1 & 2 & 3 & 4 & 5 & 6 & 7 \\
\hline Very imp. & & & & & $1.295(.078)^{* *}$ & $1.191(.080)^{* *}$ & $1.073(.082)^{* *}$ \\
\hline Essential & & & & & $1.715(.070)^{* *}$ & $1.540(.075)^{\star *}$ & $1.358(.081)^{*+*}$ \\
\hline \multicolumn{8}{|c|}{ Importance of computer use five years ago } \\
\hline Not v.imp. & & & & & & $.040(.073)$ & $.010(.072)$ \\
\hline Fairly imp. & & & & & & $.226(.074)^{* *}$ & $.206(.074)^{* *}$ \\
\hline Very imp. & & & & & & $.254(.076)^{* *}$ & $.218(.075)^{*+}$ \\
\hline Essential & & & & & & $.393(.069)^{* *}$ & $.316(.070)^{* *}$ \\
\hline Constant & $3.176(.066)^{* *}$ & $2.966(.108)^{* *}$ & $2.631(.102)^{* *}$ & $2.530(.103)^{* *}$ & $1.982(.104)^{* *}$ & $1.992(.104)^{* *}$ & $1.982(.103)^{* *}$ \\
\hline$R^{2}$ adj. & .015 & .023 & .163 & .184 & .303 & .319 & .333 \\
\hline
\end{tabular}

Note: The data are taken from the Skills Survey of the Employed British Workforce. ${ }^{*}=$ significant at the 5 percent level, and ${ }^{* *}=$ significant at the 1 percent level. All estimates are OLS. The age group 20-29 is taken as the reference group in the first row of the table. The gender dummy equals one if gender is female and zero if gender is male. The educational levels are defined according to the British classification from low to high (NVQ 1 to University) and no educational degree is taken as the reference group. The level of sophistication of computer use is defined in line with the definition in table 2. The "simple" level of sophistication is taken as the reference group. The importance of computer use is defined in line with the definitions in table 2 . The reference group are users whose computer use is "not very important". 
use and computer skills. This finding is straightforward because more complex computer tasks require a higher level of computer skills. Including the level of sophistication of computer use five years prior to the survey date indicates that it is important for the level of computer skills whether a workers uses the computer for a while. The results also suggest that it is not very important at what level of sophistication the computer has been used, since we cannot statistically discriminate between the coefficients. This seems to suggest that to accumulate computer skills it does not really matter at what level of sophistication the computer has been used, as long as workers have experience with using computers at work. The results reported in column (3) and (4) show that older workers embody a significantly lower level of computer skills than younger workers, which suggests that older workers have more trouble using a computer than younger workers. What is also interesting to note is that the level of education does not have a significant impact on the level of computer skills. This suggests that rather than the higher educational level itself, other variables explain why higher-skilled workers embody on average higher levels of computer skills.

Column (5) and (6) report the regression results of estimating equation (3). Similar to the results on the level of sophistication of computer use, the importance of computer use is positively correlated with the level of computer skills. Using a computer five years prior to the survey date has a significant positive impact on the level of computer skills, except when the computer has been not very important for carrying out the job. What is again interesting to observe is that age and computer skills are negatively correlated. The major gap in skills is found however between the age group 20-29 and all other workers ( $>30$ years old). Workers above the age of 50 do not embody significantly lower levels of computer skills that their 30 49 year old colleagues. It is also interesting to note that the explanatory power of the results in column (5) and (6) is much higher than in the previous columns. This suggests that the importance of computer use is a more important variable in understanding the level of computer skills than the level of sophistication of computer use. Including both the level of sophistication and the importance of computer use in one regression, indeed shows that the importance of computer use is more important than the level of sophistication of computer use (column (7)).

\subsection{The returns of computer skills}

The analyses so far have shown that although older workers have the same probability to use a computer as younger workers under equal circumstances, their skills to operate a computer effectively seem to be lower. The remaining question is whether this lower level of computer skills deteriorates their labor-market position. To determine the returns to computer skills we estimated a simple wage equation:

$$
\ln W_{i}=C_{i}+X_{i} \alpha+\beta S_{i}+\varepsilon_{i}
$$

The results of this regression are reported in table 6 . The coefficients at the four highest levels do not significantly differ from each other. All workers receive 22-25 percent higher wages; workers with almost no computer skills gain less. A possible reason for the lower 
Table 6

OLS regression estimates of the effect of computers on pay for all age groups (dependent variable: log hourly wage)

\begin{tabular}{|c|c|c|c|c|}
\hline & 1 & 2 & 3 & 4 \\
\hline Constant & $.581(.147)^{* * *}$ & $-.064(.292)$ & $.434(.170)^{*}$ & $-.468(.338)$ \\
\hline $\begin{array}{l}\text { Education } \\
\text { NVQ } 1 \\
\text { NVQ } 2 \\
\text { NVQ 3 } \\
\text { Professional } \\
\text { University }\end{array}$ & $\begin{array}{l}.057(.039) \\
.139(.039)^{* * *} \\
.156(.034)^{* * *} \\
.270(.040)^{* * *} \\
.373(.043)^{* *}\end{array}$ & $\begin{array}{l}.018(.077) \\
.163(.059)^{* * *} \\
.169(.064)^{* *} \\
.296(.068)^{* *} \\
.371(.072)^{* *}\end{array}$ & $\begin{array}{l}.058(.039) \\
.139(.029)^{* * *} \\
.158(.034)^{* * *} \\
.269(.040)^{* * *} \\
.373(.043)^{* *}\end{array}$ & $\begin{array}{l}.005(.077) \\
.153(.059)^{*} \\
.165(.064)^{*} \\
.281(.068)^{*} \\
.360(.072)\end{array}$ \\
\hline $\begin{array}{l}\text { Age } \\
\text { Age squared }\end{array}$ & $\begin{array}{r}.048(.007)^{* *} \\
-.000(.000)^{* *}\end{array}$ & $\begin{array}{r}.081(.014)^{* *} \\
-.001(.000)^{* *}\end{array}$ & $\begin{array}{r}.057(.009)^{* *} \\
-.001(.000)^{* *}\end{array}$ & $\begin{array}{r}.105(.017)^{*} \\
-.001(.000)^{*}\end{array}$ \\
\hline $\begin{array}{l}\text { Computer skills } \\
\text { 1. Very high } \\
\text { 2. High } \\
\text { 3. Intermediate } \\
\text { 4. Low } \\
\text { 5. Very low }\end{array}$ & $\begin{array}{l}.190(.030)^{* * *} \\
.208(.029)^{* * *} \\
.220(.041)^{* * *} \\
.178(.044)^{* * *} \\
.071(.048)\end{array}$ & $\begin{array}{l}.307(.066)^{* *} \\
.328(.067)^{* *} \\
.316(.080)^{* *} \\
.271(.088)^{* *} \\
.298(.133)^{*}\end{array}$ & & \\
\hline $\begin{array}{l}\text { Computer skills of } \\
\text { younger workers } \\
\text { (aged 20-49) } \\
\text { 1. Very high } \\
\text { 2. High } \\
\text { 3. Intermediate } \\
\text { 4. Low } \\
\text { 5. Very low }\end{array}$ & & & $\begin{array}{l}.208(.032)^{* * *} \\
.208(.031)^{* * *} \\
.247(.045)^{* * *} \\
.190(.049)^{* * *} \\
.096(.057)\end{array}$ & $\begin{array}{l}.339(.072)^{*} \\
.336(.072){ }^{*} \\
.344(.088))^{*} \\
.292(.096)^{*} \\
.355(.169)^{*}\end{array}$ \\
\hline $\begin{array}{l}\text { Computer skills of } \\
\text { older workers } \\
\text { (aged 50-60) } \\
\text { 1. Very high } \\
\text { 2. High } \\
\text { 3. Intermediate } \\
\text { 4. Low } \\
\text { 5. Very low } \\
\text { 6. Not using a } \\
\text { computer }\end{array}$ & & & $\begin{array}{l}.221(.067)^{* *} \\
.347(.068)^{* * *} \\
.242(.087)^{* *} \\
.259(.102)^{*} \\
.113(.095) \\
.116(.059)^{*}\end{array}$ & $\begin{array}{l}.447(.109)^{*} \\
.605(.114)^{*} \\
.483(.150)^{*} \\
.541(.186)^{*} \\
.416(.212)^{*} \\
.281(.158)\end{array}$ \\
\hline $\mathrm{R}^{2}$ & .414 & .321 & .414 & .324 \\
\hline
\end{tabular}

Note: The data are taken from the Skills Survey of the Employed British Workforce. ${ }^{*}=$ significant at the 5 percent level, and ${ }^{* *}=$ significant at the 1 percent level. All estimates are OLS. Standard errors are in parentheses behind the coefficients. Educational levels are classified in five categories, which correspond to the British classifications. All regressions include industry and occupational dummies as well as tenure, marital status, gender, marital status*gender, and union membership. With respect to the educational levels we take workers without a qualification are the reference group. In columns (1) and (2) workers who do not use a computer are taken as the reference group. In columns (3) and (4) younger workers (20-49) not using a computer are taken as the reference group. The variables concerning computer use, level of sophistication of computer use and computer skills are defined in accordance with the definitions in table 2. Other dummies include experience and experience squared, gender, married and married ${ }^{*}$ gender, and whether a worker is a union member and supervises other workers. Column (1) reports the regression results for the sample as a whole. Column (2) includes only those workers who already used a computer in 1992 (five years prior to the survey date). In columns (3) and (4) the same regression results are reported for workers aged 20-49 and 50-60. 
wage gain for workers with a "very low" level of computer skills is that many of these people started to use the computer only recently. Since the previous findings suggest that wages are a main determinant for computer use, recent users will on average have lower wages. In addition, since experience is an important determinant of computer skills, this result might indicate that the recent (lower-paid) users, are still inexperienced. Column (2) reports estimates excluding those workers who did not use a computer five years ago. The results show that particularly the coefficient for the least computer skilled workers has gone up. This seems to suggests that workers who use the computer for a longer period of time receive the same wages, regardless of their level of computer skills. Performing the same analysis for the workers age 50-60 gives similar results, except for the least skilled; they still earn the lowest wages (column (3) and (4)).

These results putting forward the value of computer skills are interesting. Due to the strong correlation between the level of sophistication of computer use and computer skills reported in table 4, one might expect a positive correlation between computer skills and wages too, even if computer skills are not relevant for these jobs. So even without controlling for the level of sophistication of computer use, these findings suggest that computer skills do not yield labor-market returns. These findings are consistent with the hypothesis that skills are not a main determinant of computer use. ${ }^{17}$

\section{Concluding remarks}

Do older workers have more trouble using a computer than younger workers? The answer to this question is positive when comparing the youngest workers $(20-29)$ to the others workers. The answer is not positive when comparing the oldest group of workers (50-60) to the others.

The primary goal of this study have been to clarify trends in computer use among different age groups. The analysis has yielded three conclusions. First, it is shown that computer use does not seem to be dependent on age: computer use is likely to be mainly determined by the wage level. Second, the regression results predict a negative relationship between age and the level of computer skills suggesting that younger workers embody more computer skills than their older colleagues. Third, does it matter? Apparently not, since the regression results suggest no significant labor-market returns to computer skills. These results make an important contribution to the existing literature on the impact of computerization on the labor market because they indicate that older workers do not have particular difficulties to transform and adapt to a computerized work environment. It also indicates that computer skills are not important in determining labor-market success.

17. Borghans and Ter Weel (2002c) show that in some instances computer skills yield labor-market returns when analysed separately for levels of sophistication. In such a setting only at the advanced level of sophistication of computer use their are significant labor-market returns to computer skills. 
Since only information about the workers actually using a computer is available in the data, some caution with interpreting the results might be required. The data might be a biased sample because many older workers might be forced into early retirement because of the introduction of the computer at work. This is however unlikely to be a major problem because the regression results indicate that within the group of older workers, the level of computer skills is irrelevant for their labor-market position. In addition, there appears to be no evidence when investigating the data by industry and occupation that industries heavily using computers have experienced a higher rate of early retirement relative to other industries or that particular occupational categories contain less older workers because of computerization.

\section{References}

Aghion, P., 2002. Schumpeterian growth theory and the dynamics of income inequality. Econometrica 70, forthcoming.

Aghion, P., Howitt, P. and Violante, G.L., 1998. Technology, knowledge and within-group inequality. Mimeo, University College London.

Ahituv, A. and Zeira, J., 2001. Technical progress and early retirement. Mimeo, Hebrew University. Allen, S.G., 2001. Technology and the wage structure. Journal of Labor Economics 19, 440--483.

Autor, D.H., Katz, L.F. and Krueger, A.B., 1998. Computing inequality: Have computers changed the labor market? Quarterly Journal of Economics 113, 1169--1213.

Autor, D.H., Levy, F. and Murnane, R.J., 2001. The skill content of recent technological change: an empirical exploration. NBER Working Paper 8337.

Bartel, A.P. and Sicherman, N., 1993. Technological change and retirement decisions of older workers. Journal of Labor Economics 11, 162--183.

Borghans, L. and Ter Weel, B., 2001. What happens when agent $T$ gets a computer? MERIT Research Memorandum 2001-018.

Borghans, L. and Ter Weel, B., 2002a. Computers, skills and wages. Mimeo, ROA/MERIT, Maastricht University.

Borghans, L. and Ter Weel, B., 2002b. The diffusion of computers and the distribution of wages. Mimeo, ROA/MERIT, Maastricht University.

Borghans, L. and Ter Weel, B., 2002c. Do we need computer skills to use a computer? Evidence from Britain. Mimeo, ROA/MERIT, Maastricht University.

Braverman, H., 1974. Labor and Monopoly Capital. Monthly Review Press, New York.

Bresnahan, T.F., Brynjolfsson, E., and Hitt, L.M., 2002. Information technology, workplace organization, and the demand for skilled labor: firm-level evidence. Quarterly Journal of Economics 117, 339--376.

Caroli, E. and Van Reenen, J., 2001. Skill biased organizational change? Evidence from a panel of British and French establishments. Quarterly Journal of Economics 116, 1449--1492. 
Caselli, F., 1999. Technological revolutions. American Economic Review 89, 78--102.

Chennells, L. and Van Reenen, J., 1997. Technical change and earning in British establishments, Economica 64, 587--604.

Committee for Economic Development, 1999. New opportunities for older workers. Statement by the Research and Policy Committee of the Committee for Economic Development.

DiNardo J. and Pischke, J.-S., 1997. The return to computer use revisited: Have pencils changed the wage structure too? Quarterly Journal of Economics 112, 291--303.

Doms, M, Dunne, T. and Troske, K.R., 1997. Workers, wages and technology. Quarterly Journal of Economics 112, 253--290.

Entorf, H. and Kramarz, F., 1997. Does unmeasured ability explain the higher wages of new technology workers? European Economic Review 41, 1489--1509.

Farber, H.S., 1996. The changing face of job loss in the United States, 1981-1993. NBER Working Paper No. 5596.

Freeman, C. and Soete, L., 1994. Work for All or Mass Unemployment? Computerized Technical Change into the $21^{\text {st }}$ Century. Pinter, London.

Friedberg, L., 2001. The impact of technological change on older workers: evidence form data on computers. NBER Working Paper 8297.

Garicano, L., 2001. Decentralization and inequality: the impact of information technology on organizational structure and income distribution. Mimeo, University of Chicago.

Gould, E.D., Moav, O. and Weinberg, B.A., 2001. Precautionary demand for education, inequality, and technological progress. Journal of Economic Growth 6, 285--315.

Greenwood, J. and Yorukoglu, M., 1997. 1974. Carnegie Rochester Conference Series on Public Policy 46, 49--95.

Juhn, C., 1992. Decline of male labor market participation: the role of declining market opportunities. Quarterly Journal of Economics 107, 79--122.

Krueger, A.B., 1993. How computers have changed the wage structure: evidence from microdata, 1984-1989. Quarterly Journal of Economics 108, 33--60.

Levy, F. and Murnane, R.J., 1996. With what skills are computers a complement? American Economic Review 86, 258--262.

Lindbeck, A. and Snower, D.J., 2000. Multitask learning and the reorganization of work: from tayloristic to holistic organization. Journal of Labor Economics 18, 353--376.

Lloyd-Ellis, H., 1999. Endogenous technological change and wage-inequality. American Economic Review 89, 47--77.

Peracchi, F. and Welch, F., 1994. Trends in labor force transitions of older men and women. Journal of Labor Economics 12, 210--242.

Spenner, K.I., 1985. The upgrading and downgrading of occupations. Review of Educational Research 55, 125--154.

Staiger, D. and Stock, J.H., 1997. Instrumental variables regression with weak instruments. Econometrica 65, 557--586. 
Violante, G.L., 2002. Technological acceleration, skill transferability and the rise in residual inequality. Quarterly Journal of Economics 117, 297--338.

Weinberg, B.A., 2000. Computer use and the demand for female workers. Industrial and Labor Relations Review 53, 290--308.

Weinberg, B.A., 2001. Experience and technology adoption. Mimeo, Ohio State University. 